\title{
A TERMÉSZET TÖRVÉNYEI VERSUS A TÁRSADALOM SZABÁLYAI A KÖZGAZDASÁGTANBAN
}

\section{THE LAWS OF NATURE VERSUS THE RULES OF SOCIETY IN ECONOMICS}

\author{
Róna Péter \\ Fellow, Blackfriars Hall, Oxford University, Oxford, Egyesült Királyság \\ peter.rona@bfriars.ox.ac.uk
}

\begin{abstract}
ÖSSZEFOGLALÁS
A tanulmány a következő álításokat elemzi és védi: 1. A természettudományok módszere nem honosítható a közgazdaságtanban, mert a gazdasági jelenségek ontológiája gyökeresen más, mint a természeté; 2. A gazdaságot nem okozati összefüggések, hanem szabályok irányítják; 3 . A természettudomány módszere - ide értve a matematika alkalmazását - kiszorítja a közgazdaságtan tartományából a szándékosságot a cselekvés modellezéséből, megfosztja a cselekvő embert szabad akaratától, amiért az így felépített közgazdaságtannak nincs erkölcsi tartalma; 4. A modern közgazdaságtan nem ismeri fel az emergence (felbukkanás) jelenségét, ezért nem tud figyelembe venni olyan tényezőket, amelyek nem állnak kauzális viszonyban az elemzés tárgyával.

A javasolt alternatíva a közgazdaságtan küldetésének átfogalmazása. Ne arra a kérdésre keresse a választ, hogy mi van (res extensa), hanem arra, hogy mi lehet és legyen (res potentia), hogy milyen kritériumok alapján mit lehetne és mit kellene megalkotni.
\end{abstract}

\section{ABSTRACT}

This paper analyses and defends the following claims: 1 . The methodology of natural sciences cannot be domesticated in economics because the ontology of economic phenomena is radically different from that of nature; 2 . The economy is animated by rules rather than causal relationships; 3. Use of the methodology of natural sciences in economics banishes intentionality in the modelling of economic activity, deprives the agent of his free will, with the result that economics so constructed has no moral content; 4 . Modern economic theory fails to recognise emergence where the components are not in a causal relationship with the object of investigation.

The proposed alternative rests on a redefinition of the mission of economics. It should abandon seeking an analytic understanding of what is (res extensa) and, instead, concern itself with how individual and collective agents reach decisions about what could and should be done (res potentia), and how the desired objective could and should be achieved.

Kulcsszavak: szándékosság, okozati összefüggés, kauzalitás, reflexivitás, erkölcs, érték, felbukkanás, matematika, tárgyiasítás

Keywords: intentionality, causation, causality, reflexivity, morality, value, emergence, mathematics, objectification 
A modern közgazdaságtan a tudományosságra törekszik, s a tudományosságot a természettudományoktól kölcsönkért módszerek alkalmazásával biztosítja. Mivel a természettudományok a törvényszerüségeket a kauzális összefüggésekre építik, a közgazdaságtan 19. századi tudósai is a kauzális kapcsolatokat keresték, még akkor is, ha törekvéseik a tudomány tartományának olyan meghatározását eredményezték, amelynek a megtapasztalható realitásokhoz egyre szerényebb lett a kapcsolata. A természet folyamatainak és jelenségeinek ugyanis nincs erkölcsi tartalmuk; a természettudományok módszere értelemszerủen kizárja figyelme tartományából a gazdasági élet azon elemeit és tényezőit, amelyek a gazdasági döntések és cselekedetek erkölcsi indítását, tartalmát magukban hordják. A tanulmány a természettudományok módszertanának átültetését vizsgálja a közgazdaságtanba, és felméri az átültetés tudományos és gyakorlati problémáit.

\section{FISZISZÉS NOMOSZ}

A természeti jelenségek egysége, majd kiterjesztve, az összes empirikusan megtapasztalható jelenség egysége szinte a kezdetektől foglalkoztatja a filozófiát. A szofisták tagadják az egységet, különbséget tesznek a természeti (fiszisz) és a társadalmi törvények (nomosz) között, Arisztotelész pedig négyféle okozati öszszefüggést (aitia) különböztet meg (Arisztotelész: Fizika, II.3). Szerinte minden tudománynak megvan a saját tartománya, és az adott tartomány tanulmányozásához alkalmas módszertana. A jelenségeknek tehát nincs ontológiai egységük, és magyarázatukra, értelmezésükre nem lehet egy egységes eszköztárat kovácsolni. Platón szerint, szöges ellentétben Arisztotelésszel, a természet egy test, amelyet, ahogy azt az ügyes hentes teszi, a tudomány az ízületek mentén darabolja a megértést előmozdító részegységekre (Phaidrosz, 265d-266a). Arisztotelész nem látja a természet egységét, de a helyzet közel sem reménytelen, mert van ,közös nevezőjük": a telosz, amire alapozva az egymástól eltérő jelenségeket meg lehet érteni. A fizika, a biológia, de az emberi viselkedés megnyilvánulásai is a természetükben rejlő telosz, azaz cél alapján értelmezendők. A cél persze a jelenség tárgyának természetéből és nem valamiféle általánosított, elvont törvényszerüségből vonható le. A kő azért esik a föld felé, mert ott van a helye, ez a kő természete. A madarak azért repülnek ősszel dél irányába, hogy túléljék a telet. A test részei és szervei azért vannak, hogy a testet segítsék rendeltetésének megvalósításához.

A teleológia, tehát az arisztotelészi teloszra épített tudományfilozófia, szinte zavartalanul uralta a nyugati tudományt egészen Johannes Kepler (1571-1630) és Galileo Galilei (1564-1642) munkásságáig. Kepler és Galilei számításai és kísérletei alapjaiban cáfolták az arisztotelészi természettudományt, óriási felfordulást okozva az európai tudat szerkezetében, a tudományon kívül a teológiában, de a politika, az államigazgatás és a jog elméletében is, azzal, ahogy kiüzték az 
ún. „naturalista” célirányú elméletet. Helyette, részben visszanyúlva Platónhoz, Galilei a matematikát nevezte meg mint a természet egységének kifejezőjét és szavatolóját. Szerinte ez a természet egységes nyelve. De Galilei számára a matematika nem a természetben tapasztalható formák, egységek és arányok absztrakt, tehát platóni idealizálás gyümölcse, hanem maga a természet esszenciája, szerkezete, a természet ontológiájának a lényege, a mai fogalmat metaforaként alkalmazva, a természet DNS-e. Miközben a platóni absztrakt formák elmélete nem jelenti azt, hogy a természet minden aspektusa visszavezethetö lenne a matematikára, Galilei szerint nincs olyan természeti jelenség, ami nem a matematika közvetlen kifejeződése lenne: „Egli ${ }^{*}$ è scritto in lingua matematica, e i caratteri son triangoli, cerchi ed altre figure geometriche senza i quali mezzi è impossibile a intenderne umanamente parola."

A matematika a természettudományok mindent átfogó magja - Descartes szóhasználatában Mathesis Universalis -, amiből és aminek szabályai szerint aztán a mechanika vagy a gravitáció törvénye levezethető. A Teremtés egy gép, olyan, mint egy óra, és Isten a Nagy Órásmester.

A matematikára épített új tudomány nagy müvelői mindegyikének - Kopernikusz, Kepler, Galileo, Descartes, Newton vagy Leibnitz - felfogásában nem matematikai eredményeik teszik szükségessé Isten szerepének átírását, hanem fordítva: éppen Isten új értelmezése teszi lehetővé a matematika gyökeresen megváltozott értelmezését. A középkor teológiájában, mint például Aquinói Szent Tamás, Avicenna vagy Maimonidész írásaiban a transzcendens és végtelen Isten és az arisztotelészi véges természet közötti feszültség feloldatlan marad. Galilei axiómája szerint Isten a racionalitás nélkülözhetetlen forrása és megtestesítője, hiszen az univerzum szerkezetét Ö írta meg, azt nem a véletlen hozta létre. A haragos és kifürkészhetetlen Isten helyét átveszi a Nagy Órásmester képe. A híd tehát, amely összeköti a zsidó-keresztény transzcedentális monoteizmust az ógörögök racionalitásával nem más, mint a matematika, aminek segítségével a korábbi feszültség feloldódik.

A megoldásnak azonban nagy ára van. A szabad akarat helyét elfoglalja a matematikailag determinált világ. Ha pedig nincs szabad akarat, nincs mire építeni az emberi cselekvés értelmezését, az ember erkölcsi felelősségét. Ha az Univerzum egésze a matematika nyelvén íródott, miért lenne az ember természetének más a nyelve? Ha a természet egészét lefedi, törvényeit megvilágítja a matematika, miért létezhetne bármiféle valóság, amit nem a matematika ellenőrizne? Beindult, majd a 20. század első felében csúcspontjára ért az élet minden aspektusának matematizálására tett kísérlet. A tudás egységes, annak minden formája a matematikára vezethető vissza (Hilbert, 1925). Meg is születik a társadalomtudományokat, így a közgazdaságtant is maga alá kényszerítő axióma: ami nem mérhető, nem is

\footnotetext{
"„Egli”, itt a Teremtés egészére utal.
} 
létezik. Az ember rajta kívül álló törvények tárgyává válik, nincs önálló, a természettől független akarata. A társadalomtudományok eszköztára alkalmazkodik a matematika követelményéhez; olyan fogalmakat hoz létre, amelyek eleve alkalmasak a számszerüsítésre. A számszerüsítés igénye határozza meg a tudomány tárgyát, és nem a tudomány tárgya a számszerúsítés alkalmazását. Léon Walras szerint $(1874,1926)$ a fogalmak a tapasztalat absztrahálásából születnek, de nem derül ki, hogy mi igazolja az absztrahálást. Maga a számszerüsítés kritériumának való megfelelés legitimálja a modern közgazdaságtan elméleteit, áthágva a természettudomány bizonyítási rendszerének alaptételét, nevezetesen az elmélet függetlenségét annak tárgyától. A racionális választás elmélete (rational choice theory) az összemérhetetlen aspektusokkal rendelkező döntéshozatali folyamatot úgy teszi összemérhetővé, hogy a döntések tényleges tényezői helyébe a valóságban nem tapasztalható döntési egységeket, ún. preferenciákat konstruál, amelyek által a dolgokat kardinálisan, majd finomított változatában sorrendi sorba lehet rendezni. Teszi ezt annak ellenére, hogy e rendezés nem felel meg a döntéshozatali folyamat tulajdonságának, ami eleve az összemérhetetlen dolgok figyelembevételével a döntéshozó szándéka szerint hozza meg eredményét.

\section{A MATEMATIKA SZEREPÉNEK AZ ÚJRAÉRTELMEZÉSE}

Miközben a társadalomtudományok az embert megfosztották szabad akaratától, egy determinált, akaratát felülíró rendszerbe kényszerítették, a természettudományok, jelesen a fizika, az ellenkező irányba mozdult el. Galilei determinizmusának végét talán legelőször Erwin Schrödinger Über Indeterminizmus in der Physik (1934) tanulmánya fogalmazza meg. Wigner Jenö 1960-ban megjelent The Unreasonable Effectiveness of Mathematics in the Natural Sciences (Wigner, 1960) címü tanulmánya, követve Schrödingert, tagadja a matematika valóságot leképző képességét, helyette a matematika hatékonyságát, majd e hatékonyság megmagyarázhatatlanságát boncolgatja. Wigner számára ugyanis, mint a 20. század fizikusai számára, a 'valóság' fogalma elvesztette értelmét. A matematika Wigner szerint nem a valóság igazmondó tükre, hiteles ábrázolója - a valóságot végső soron nem lehet leképezni -, hanem a természet megértéséhez vezető leghatékonyabb eszköz. A matematika nem azért hatékony (pace Galilei), mert a természet kódja, hanem azért, mert mint ismeretelméleti eszköz, ez biztosítja leginkább a természeti jelenségek és folyamatok empirikusan is többé-kevésbé bizonyítható megértését. A kapcsolat nem más, mint egy csodálatos, de rejtelmes és megfejthetetlen 'ajándék'.

Csakhogy a társadalomtudományok esetében nem erről a rejtelmes egybeesésről van szó, ami vagy van, vagy nincs. Ha nincs, a természet nem változik meg a matematika alkalmazásának hatására. Legfeljebb kiderül, hogy a folyamatok 
megértéséhez a matematika további fejlödésére van szükség, mint például Albert Einstein relativitáselmélete esetében, amelynek matematikai ábrázolására és bizonyítására csak Einstein halála után kerülhetett sor. Egy téves kauzális természettudományi elmélet nem hoz változást a természet törvényeiben. De a társadalmi folyamatok „reflexívek”, az elmélet befolyásolja, bizonyos esetekben ex nihil előteremti magát a folyamatot, amit az elmélet lenne hivatott megvilágítani. A gazdaság matematikai modellezése tehát egy félrevezető, hiú ábránd, ami nem tár fel semmiféle ismeretlen, de létező valóságot, hanem magát az elmélet által megfogalmazott, az elmélet hiányában nem vagy csak részben létező valóságot hozza létre. De a gazdasági elméletek óriási társadalmi, erkölcsi, környezeti és anyagi romboláshoz vezethetnek. Ebben az értelemben - tehát valóságteremtő képességében és hatásában - a közgazdaságtan átlépi a tudomány kereteit, Daniel Hausman (1992) szavaival élve, egy „pontatlan és különállo’” tudomány, ami saját maga hozza létre tárgyát.

A tudományosság látszatát a közgazdaságtan a szándékosság (intentionality), kiiktatásával hozza létre. A 20. század első felére a szándékosság kimarad a tudás minden legitim formájából. A társadalom szabályai a társadalom szándékától független törvényekből erednek, legyen az Karl Marx történelmi determinizmusa, Charles Darwin evolúcióelméletére alapozott társadalomfilozófia, Sigmund Freud tudat alatti mechanizmusa vagy a liberális közgazdaságtan a fizikától átvett egyensúly (equilibrium) metaforája. Mindegyik esetben az ember és társadalma elveszíti szabad akaratát, de paradox módon, éppen az elmélet a hivatkozási pontja azoknak a szándékosan felépített intézményes berendezkedéseknek, amelyek nélkül az elmélet nem valósulna meg. Az Arrow-Debreu általános equilibrium-elmélet például tizennégy, a természetben nem létezö feltételezésre épül, amelyek egy része (a tizennégy közül kilenc) meg sem valósítható, miközben a további öt komoly, törvénybe iktatott és karhatalmi erővel érvényesített szabályozást igényel, szemben a vízcseppel, amelynek létrejöttéhez nem kell intézményrendszer.

Ha a természeti jelenségeknek nincs céljuk, ha a világ rendjét sem az isteni irányítás, sem pedig az arisztotelészi telosz harmóniája nem biztosítja, hanem a természet nyelve, azaz Galilei matematikája, a jelenségeket éppúgy értelmetlen az abban rejlő szándékok alapján értelmezni, mint a számok vagy a geometriai formák bármelyikének céltudatot, szándékosságot tulajdonítani. De a társadalomtudományok az ember természetével foglalkoznak, azokkal a cselekedetekkel, amelyeket az ember tudatosan, szándékosan hajt végre. Ha kétségtelen, hogy a vízcsepp nem az oxigén és a hidrogén egyesülési szándékából jön létre, és a természeti jelenségek szándékmentességét kiterjesztjük az ember viselkedésére, mivel magyarázzuk, hogy az ember egyszer bort iszik, máskor meg sört vagy limonádét? Hogyan írható le az egyén és a társadalom szerkezete úgy, hogy az megfeleljen a matematika nyelvének? 
Galilei és Newton mechanikus világrendjét talán elsőként Adam Smith alkalmazta a gazdasági folyamatok tanulmányozásában. Smith az önérdek követésében látja azt a közös nevezőt, amely mentén minden egyén meghozza gazdasági döntéseit. Elismeri, hogy az önérdek felfogása és üzése egyénenként eltér egymástól - tehát ezen a szinten még nem látható a törvényszerüség -, de az egyének eltérö, sokszor egymással versengő és egymásnak ellentmondó céljait egy (vagy a) láthatatlan kéz („Invisible Hand”) harmonikus rendszerré varázsolja. Az egyéni érdek üzése ezáltal a közérdeket szolgálja. A természettudomány gyors fejlődése azonban már egyre kevésbé kedvezett a láthatatlan kezekre alapozott elméleteknek. Mivel lehetne helyettesíteni a Láthatatlan Kezet? Newton lenyügöző sikere a társadalomtudósokat és filozófusokat is a természettudományok módszertanának minél nagyobb mértékü honosítására késztette. David Ricardo, majd John Stuart Mill és Jeremy Bentham a tapasztalat tárgyiasításába veti reményét, de hamar kiderül, hogy a társadalomtudomány csak akkor tudná követni a természettudományt, ha képes lenne a megfelelő axiómák megfogalmazására.

De milyen axiómákra van szükség? Olyanokra, amelyek az okozati összefüggéseket tárják fel, vagy olyanokra, amelyek a gazdasági cselekvés értelmezésének biztosítanak kiindulópontot? Mi a közgazdaságtan feladata: az előrejelzés, ami a természettudomány jellegzetessége, és amihez egy megfelelő kauzális elmélet kialakítása szükséges, vagy a folyamatok és jelenségek értelmezése, tehát az inditékok feltárása? A két megközelítés közötti feloldhatatlan feszültség jellemzi és végigkíséri a 19. század közgazdaságtanát. Az első a természetben felfedezhető univerzális, kivétel nélküli, helytől és időtől független és szándékosságtól mentes okozati összefüggésekröl szól, amelyek alapján egy adott helyzet kimenete elöre jelezhető. (Ha a hőmérséklet 0 fok alá süllyed, a víz megfagy. Ha nő a munkanélküliség, csökken az infláció. Csak hát, a víz tényleg megfagy, de az infláció nem biztos, hogy csökken.) A második azokról az inditékokról, amelyek az embert az adott cselekvésre késztetik (segítek a testvéremnek, mert szeretem), és amelyek morális értékelése együtt történik a döntéshozatal folyamatában a hasznosság és a hatékonyság figyelembevételével. Az utóbbi esetében a közgazdaság tárgya a jövő, a várható kimenet mérlegelése, az, hogy mi legyen és miért?

Marx például a materialista determinizmus és a humanista racionalizmus hagyománya között őrlődik; egy igazságos tudomány megalkotására törekszik. De igazságos tudomány nincs. A természet nem igazságos, az igazságosság nem a természet, hanem a társadalom terméke. John Maynard Keynes rendre felhívja a figyelmet a belső, az ember lelkiismeretében és eszében zajló folyamatokra, a gazdasági folyamatok képlékenységére, és elutasítja a determinista gondolkodást, de ennek ellenére keresi a törvényszerü összefüggéseket. Bár Alfred Marshall empiricizmusa egyáltalán nem zárja ki az erkölcsi megfontolásokat, nem tud velük mit kezdeni, nem tudja azokat beilleszteni a rendszerébe, mert a kauzális természeti törvények és az indítékalapú társadalmi szabály között nincs olyan 
közös ontológiai tulajdonság, amely a kettőt összemérhetővé tenné. Mill hiába javasolja az adott kimenethez hozzájáruló tényezők szétválasztását és elkülönített elemzését, a kísérlet kudarcba fullad, mert az okokat és az indítékokat nem lehet szétválasztani erős és irreális előfeltételek bevonása nélkül. Ráadásul, a szétválasztásnak csak akkor lenne értelme, ha az egymástól elkülönített okokat és okozatokat egy egységes, számszerüsített mérőrendszerbe lehetne állítani, ami csak akkor lenne lehetséges, ha a tényezők összemérhetőek lennének. De nem azok.

Hiába a mai napig is alkalmazott ceteris paribus elöfeltétel, az erre alapozott modell nem müködik, elsősorban nem azért, mert a figyelmen kívül hagyott (exogén) tényezők a valóságban nem maradnak azonosak, hanem azért, mert a gazdasági folyamatokra éppen az a jellemző, hogy a releváns tényezők bármelyikében bekövetkezett változás a többi tényezöre is hatással lehet. Pontosabban fogalmazva, az egyik tényező változása nem a másik tényezőre, hanem a folyamatban részt vevő emberre van hatással, aki a hatás következtében megváltoztatja viselkedését, amivel aztán a többi tényezőben változást idéz elö. Azt, hogy melyekben és milyen mértékben, nem valamiféle, a tényezők közötti kauzális összefüggés, hanem a cselekvő ember határozza meg. Lehetséges döntésének paramétereit - de csak a paramétereit - pedig a társadalom szabályai rögzítik. Minden gazdasági esemény az emberen keresztül zajlik, minden esemény az ember döntésének, alkotó- és képzelőerejének és cselekvésének az eredménye. Ráadásul, a gazdasági jelenség az összes tényező egymásra gyakorolt hatásából - beleértve a cselekvő szereplők okait - áll össze. A természeti törvényektől eltérően, ahol az eseménynek nincs jelentése, a gazdasági esemény az emberi cselekvés értelmezése alapján jön létre, az események közötti összefüggés nem az esemény tulajdonságának, hanem az esemény ember által meghatározott jelentésének a függvénye. Mill megoldása nemcsak azért nem megoldás, mert egy radikális leegyszerüsítés, hanem azért, mert a folyamatok tényezőit tárgyiasítja - a szándékos tett szándéktalan, számszerüsíthető tárggyá válik -, alapjában változtatva meg ontológiai sajátosságait. A tárgyiasított eseményből kimarad jelentésének kontingens értelmezése. A tárgyiasítás a jelenséget rögzíti, kőbe vési, miközben annak gyakran, ha nem is mindig, a képlékenység, az esetlegesség a legfontosabb tulajdonsága. Kauzális összefüggést persze csak az esetlegességtől mentes tárgyak között lehet felállítani.

A modern közgazdaságtan három sarokmodellje, az Arrow-Debreu-féle általános equilibrium-elmélet, a játékelmélet és a racionális választás elmélete tehát egyaránt egy téves kauzális elméletre épül. Mindhárom feltételezi, hogy a lehetséges kimenetek mindegyike ismert, a statisztika kifejezését használva, a sample space (mintavételi keret) elöre adott. De Keynesnek igaza volt, amikor Sir Roy Harrodhoz intézett levelében a gazdasági folyamatok és jelenségek képlékenységére, kiszámíthatatlanságára hívta fel a figyelmet, ami nem a közgazdaságtan eszköztára hiányosságának, hanem a gazdaság természetének tulajdonítható. 


\section{A GAZDASÁGI CSELEKVÉS ERKÖLCSI TERMÉSZETE}

A 19. század végére a közgazdaságtan föárama elfordul az erkölcsi kérdésektől, és a „tiszta” matematikára alapozott, a fizikát utánozni vágyó diszciplínává válik. 1874-ben megjelenik Léon Walras nagy müve, az Éléments d'économie politique pure (Walras, 1874), 1897-ben Irving Fisher már egy egész bibliográfiát - Bibliography of Mathematical Economics - publikál, Augustin Cournot Researches into the Mathematical Principles of the Theory of Wealth kötete mellékleteként (Fisher, 1897). A közgazdaságtan mint a kauzális tudományok egyike, úgy tünik, elfoglalja egyenrangú helyét a természettudományok páholyában. A „szándék” elveszíti szubjektív jellegét; mindenkinek mindenkor és mindenhol azonos egységben (a hasznosság egységében) mérhető a szándéka. Ami pedig nem mérhető ezen az alapon, az nem is létezik.

A gazdasági cselekvés természete eltér a természeti jelenségekétől. A természeti törvények arra vonatkoznak, ami van. Az emberi cselekvések azonban abból állnak össze, ami legyen; az erkölcsi kérdéseket nem lehet kizárni. A természet jelenségeit a róluk fogalmazott törvényszerüségek nem befolyásolják, a kimenetet az okozati összefüggés biztosítja emberi beavatkozás vagy rásegítés nélkül. A gazdasági folyamatok ezzel szemben az emberi cselekvés révén valósulnak meg. Miközben egy társadalmi szabály rendszeres betartása - mint például a magántulajdon tiszteletben tartása - hasonlít az okozati összefüggéseknél észlelhető rendszerességre, ahol az egyik tényezöt rendre követi a másik, a kettő közötti kapcsolat nem a tényezők tulajdonságának találkozásából származó mindenhol és mindig tapasztalható kimenet, hanem a módosítható és a történelem folyamán rendre módosított szabály eredménye. David Hume elmélete szerint nincs kauzalitás, csak ,állandó kapcsolódás" (constant conjunction), aminek rendre történő megismétlődését az ember okozati összefüggésként fogja fel. Hume híres példája a biliárdgolyók ütközése, ahol abból a tapasztalatból vonjuk le a következtetést a második biliárdgolyó mozgására vonatkozólag, hogy az első golyó mozgása mindig azonos következménnyel jár. Okozat, mint olyan, nincs, csak rendre megismétlődő kapcsolódás. Hume elmélete (és Immanuel Kant válasza az elméletre) a mai napig éles viták tárgya, de (Kant válaszával együtt) mindenképp hibás, ugyanis kauzalitás igenis létezik, az okozati összefüggés megállapítható és kiszámítható a jelenségben szereplő tényezők tulajdonságából. A két biliárdgolyó ütközésének kimenete a két golyó méretének, súlyának, anyaga rugalmasságának, a lökés erejének stb. az eredménye, és kiszámítható a golyók megfigyelése nélkül. A szikra, ami átvonul egy hidrogén és oxigén keverékén, vizet produkál, mert a $\mathrm{H}$ és az $\mathrm{O}$ vegyértéke ezt a kapcsolódást hozza létre. A társadalom szabályai azonban nem rendelkeznek a vegyértékhez hasonlítható tulajdonsággal. A tárgyak, mint a biliárdgolyók tulajdonságai (méretük, súlyuk stb.) számszerüsíthetők; a társadalmi és gazdasági jelenségeknek előbb át kell esniük a tárgyiasítás komp- 
likált és egyáltalán nem problémátlan folyamatán. A kereslet akkor válik felrajzolható görbévé, ha a tényleges kereslet helyébe feltételezésekkel alátámasztott, azonos egységekben kifejezett keresletet állítunk. De a felrajzolt görbe mögött nincs a biliárdgolyóhoz hasonlítható, a kereslet elméletétől független tulajdonságokkal rendelkező entitás.

A társadalmi szabályok nem a társadalom tagjai univerzális tulajdonságainak következményeként, hanem a legkülönbözőbb módon a történelem, a körülmények, az adottságok, a lehetőségek, az egyéni tettek keverékeként jönnek létre, és betartásuk a legkülönbözőbb eszközök alkalmazásával valósul meg. Univerzális, örökre érvényes társadalmi szabályok nem is léteznek, értelmezésük még egy adott társadalmon belül is rendre vita tárgya, betartásuk pedig további szabályok megalkotásától és érvényesítésétől függ. Az egyéni és a kollektív viselkedés mutathat esetleges, átmeneti vagy többé-kevésbé tartós hajlamosságot, statisztikailag valószínűsíthető tendenciát, de a társadalmi folyamatok történelmisége eleve kizárja a történelemmentes természeti törvények beemelését a társadalomtudományok módszertanába. A szándékosság, ami leválaszthatatlan része minden egyéni és kollektív cselekedetnek, szükségszerủen magában hordozza a szándék erkölcsi jelentését. Már a cselekvés céljának a leírása sem lehetséges valamiféle értékrend nélkül. Az érték és a tény kettőssége a társadalomtudományok esetében fenntarthatatlan (Putnam, 2002). Ludwig Wittgenstein a jelenségeket tarka színünek nevezi, ahol a különböző színű fonalak, bár különböző színủek, kibogozhatatlanok, létük lényege az együttes hatás.

\section{AZ 'EMERGENCE' (FELBUKKANÁS) ELMÉLETE}

A társadalmi intézmények létrejötte azonban nem mindig magyarázható a társadalom tagjainak szándékosságával. Tele vagyunk olyan intézményekkel, amelyeket nem mi hoztunk létre, mi több, senki sem tehető felelőssé létrejöttükért, amelyek egyszerüen létrejöttek. A társadalmi és a természeti rendszerek rendre mutatnak olyan tulajdonságokat, amelyekkel a rendszert alkotó részegységek, illetve tényezők nem rendelkeznek. Az élet például egy rendszer, müködése, fennmaradása meghatározható feltételektől függ, de létrejötte és tulajdonságai nem vezethetők vissza sem a benne zajló biokémiai folyamatok tulajdonságaira, sem a feltételekre. Sem a biokémiai folyamatok, sem a feltételek nem magyarázzák meg az életet, az élet megnyilvánulásait. Egy új rendszer létrejön (szakzsargont használva: „emerges”, azaz felbukkan) a saját, eredeti alkotórészeire visszavezethetetlen tulajdonságaival. A jelenségre a kauzalitás nem ad magyarázatot, a matematika, mint ahogy a hálózatelmélet, ami pedig a természet folyamatai megvilágításában oly gyakran hasznosnak bizonyul, egyáltalán nem segít. A szándékosság magyarázatot adhat a létrejött lehetőség kihasználására, de semmiképp 
se magyarázza annak felbukkanását. Az új rendszer létrejötte kiszámíthatatlan, nincs olyan előrejelzési módszer, ami azt előreláthatóvá tenné. Egy biológiai mutáció további, korábban előre nem látható mutációnak, illetve biológiai folyamatoknak nyit utat (Monod, 1970). Egy technológiai fejlesztés, mint a számítógép alkalmazása és alkalmazásának széles körü következménye, elöreláthatatlan. A Facebook létrejöttét nem lehetett megjósolni az IBM 701 elektronikus adatfeldolgozó gép bevezetéséből. (Maga az IBM akkori vezérigazgatója, Thomas Watson Sr. nyilatkozta a modell bemutatásakor, hogy a várható globális kereslet mintegy tizenkilenc darabra tehetö.) A gazdaságban felbukkanó termékek és szolgáltatások jellegzetessége, hogy lehetőséget teremtenek további, korábban el nem képzelt termékek, illetve szolgáltatások kialakítására (Kauffman, 2008). Ezért a technológia fejlődésének kihatása például a munkaerőpiacra kiszámíthatatlan. A jelenség sem a kauzalitás, sem a szándékosság mentén jön létre, legfontosabb aspektusa radikális antideterminizmusa. A felbukkanás elmélete éppen az elörejelzés a korábban elképzeltnél sokkal csekélyebb mozgásterét bizonyítja. Bár a jelenségre már Immanuel Kant $A z$ itélőerő kritikája címü müvében felhívta a figyelmet - megkülönböztetve a szervezett lényt, ami formáló képességgel rendelkezik a gép pusztán mozgató képességétől -, még feldolgozatlan kérdés, hogy a felbukkanás jelensége a természetben mennyire hasonlatos/azonos a társadalmi jelenségekkel, de kétségtelenül jelen van a valóság legkülönbözőbb megnyilvánulásaiban.

A legutóbbi determinista kísérlet a kognitív tudomány eredményeire építő neuro-közgazdaságtan (neuroeconomics), amely szerint az agykutatás és a kognitív tudományok mérései előbb-utóbb feltárják azokat a neurológiai utakat az emberi agyban, amelyek mentén az emberi cselekvés létrejön. De a neuro-közgazdaságtannak el kellene számolnia az emberi tudat szubjektivitásával, az indittatás eredetével, a kurrens filozófiai kifejezéseket használva, a szándék és a tudás sajátos, egyéni, internális jellegével és a fenti paragrafusban felvázolt felbukkanás jelenségével. Az előbbi teljes mértékben hiányzik, az utóbbi, tekintettel radikális antideterminizmusára, $a b$ ovo cáfolja a neuro-közgazdaságtan kutatási programját.

A természeti törvényekhez hasonló szabályosságok vélt, de teljesen hamis feltételezése a társadalomtudományokban sajnos komoly következményekkel jár: azt jelenti, hogy az emberi cselekvés törvényszerüségeknek felel meg, ezért nincs etikai tartalma. A modern közgazdaságtan az embert rajta kívül álló törvények szolgájává silányítja, megfosztva őt autonómiájától és ezzel együtt erkölcsi felelősségétöl. Ha a közgazdaságtan törvényei olyanok, mint a természettudományé, ha az oxigén nem felelős vegyértékéért, milyen alapon lenne az ember felelős kapzsiságáért, egyáltalán milyen alapon lehetne egy viselkedést kapzsinak minősíteni?

Miközben a modern közgazdaságtan kétségtelenül hozzájárult a termelési tényezők hatékony kiaknázásához, az emberiség rendelkezésére álló anyagi és tár- 
gyi javak drámai növekedéséhez, nem vitathatja felelösségét vélt tudományának tudománytalan alapjaiért, amelyekből kialakult a szélsőséges egyenlőtlenség, a társadalmi igazságtalanság és a környezet katasztrofális rombolása. Mindez történt a természettudomány ,utolérésének” felvállalt kényszeréből, ami az embertől elvette morális autonómiáját, és olyan ontológiai tulajdonságokkal helyettesítette az ember és a társadalom tényleges egyéni, illetve kollektív cselekvéseit, amelyek csak annyiban lelhetők fel azokban a cselevésekben és folyamatokban, amennyiben a közgazdaságtan téziseit kötelező érvényű szabályok érvényesítik.

A modern közgazdaságtan fösodrása már a hetvenes években válságba került, az alternatívák keresése a 2008-as világgazdasági válság után felgyorsult és kiterjedt. Az egyik ilyen irányzatot - az ún. intentional economics (szándékossági közgazdaságtan) - az Oxfordi Egyetemen a Blackfriars Hall szervezetében létrehozott, immár öt éve folyamatos kutatás képviseli. Az irányzat a diszciplína küldetésének újrafogalmazásában, elsősorban tárgya ontológiai tulajdonságainak feltárásában, a kauzális elméletek relevanciájának cáfolásában és a tárgy morális tartalmának elötérbe helyezésében látja a kiutat szemben a fősodor analitikus törekvéseivel.

\section{IRODALOM}

Fisher, I. (1897): Bibliography of Mathematical Economics. In: Cournot, A. A.: Researches into the Mathematical Principles of the Theory of Wealth. New York: Macmillan, https://www3. nd.edu/ tgresik/IO/Cournot.pdf

Galilei, G. (1890-1909): Il Saggiatore. In: Opere di Galileo Galilei. vol. VI (Favaro G. ed.) Florence: G. Barbera

Hausman, D. M. (1992): The Inexact and Separate Science of Economics. Cambridge University Press

Hilbert, D. (1925): On the Infinite. Mathematische Annalen, 95, 161-190.

Kant, I. (2003): Az itélöerö kritikája. Budapest: Osiris Kiadó

Kauffman, S. A. (2008): Reinventing the Sacred. New York: Basic Books

Monod, J. (1970): Le Hasard et la Nécessité. Paris: Éditions du Seuil

Putnam, H. (2002): The Collapse of the Fact/Value Dichotomy. Harvard University Press

Schrödinger, E. (1932): Über Indeterminismus in der Physik. Leipzig: J. A. Barth, DOI: 10.1002/ ange.19330460412

Walras, L. (1874, $5^{\text {th }}$ and final edition in 1926): Éléments d'économie politique pure. Lausanne: L. Corbaz \& Cie, https://archive.org/details/lmentsdconomiep01walrgoog/page/n5

Wigner, E. (1960): The Unreasonable Effectiveness of Mathematics in the Natural Sciences. Communications on Pure and Applied Mathematics, XIII, 1-14. https://www.maths.ed.ac.uk/ v1ranick/papers/wigner.pdf 